\title{
The Effects of Motivation and Competency on Human Resources Performance of Program Keluarga Harapan (Family Hope Program) in Banyuasin District
}

\author{
Nadia Afrilliana*, Sudarta Sudarta*, Mentari Vieka Mawarni \\ *Universitas Muhammadiyah Palembang, Indonesia \\ Email: Nadiaafrilliana@ymail.com
}

\begin{abstract}
Motivation and competence are closely related to performance. Motivation and competence felt directly by the Family Hope Program's human resources program can reduce performance or increase the performance of the Family Hope Program. This research is conducted on the Family Hope Program in Banyuasin District. This study aimed to determine the effect of motivation, competence jointly and partially on human resources performance of the hope family program in Banyuasin District. The variables in this study were motivation and competence in performance. The population in this study was 133 human resources of The Family Hope Program in Banyuasin District with 57 samples. The sampling technique in this research was Simple Random Sampling. The results of data analysis in this study showed that together motivation and competence variables had a significant effect on the human resources performance of the Family Hope Program in Banyuasin District. Individually, the motivation variable has a significant impact on performance. The competency variable did not significantly affect performance, and the competency variable significantly affected the human resources performance of the Family Hope Program in Banyuasin District.
\end{abstract}

Keywords: motivation; competence; performance.

\section{How to Cite.}

Afrilliana, N., Sudarta, S., \& Mawarni, M. V. (2021). The effects of motivation and competency on human resources performance of Program Keluarga Harapan (The Family Hope Program) in Banyuasin District. International Journal of Business, Management \& Economics. 2(2). 80-88. DOI : https://doi.org/10.47747/ijbmer.v2i2.219

\section{Introduction}

According to Wibowo (2016: 7), Employee performance is the result of work that has a strong relationship with organizational strategic goals, customer satisfaction, and contributes to the economy Motivation is a factor that encourages a person to carry out a particular activity. Therefore motivation is often interpreted as factors driving a person's behavior. Every activity carried out by someone must have a factor that drives these activities. Therefore, the support factor of a person to carry out a specific activity is generally the needs and desires of that person (Sutrisno, 2017: 110).

Competence is a skill that a person has for all aspects of the work to be carried out, and these skills make him feel capable of achieving various goals in his job. Competence has the same meaning as the word ability, skill, or expertise. Competence can provide an overview of the ability of an individual to carry out a certain task.

The performance of HR of The Family Hope Program in Banyuasin District had not yet achieved the expected performance in carrying out its duties. It could be seen from the low level of participation, there were still findings of HR who were still absent in carrying out their duties, such as absent at meetings held by the district PPKH, and there were still HRs 
who were late in submitting reports that might be submitted every month, but the reality was still there. Human resources who did not collect their duties. every month. In addition, to improve the performance of PKH human resources, that might be considered that was the provision of motivation so that human resources performance could be increased. In this case, an agency leader needed to increase motivation so that the agency's goals could be achieved and impact improving HR performance. Based on the conditions in the field when there were problems with the lack of work motivation of HR, such as the provision of compensation in the form of honorarium or additional transport provided to HR, besides that there was also a lack of appreciation given to outstanding human resources so that the decrease in performance could be said to be sufficient. There was also a lack of facilities to carry out duties in the field, making it difficult for HR to carry out their duties. Competence where there was still a lack of training obtained by human Resources, which made it difficult for human resources to carry out field tasks, such as there were still human resources who experienced difficulties in the field dealing with mothers with low education, people who did not understand the program, needed skills to be able to encourage KPM to be able to leave the program, besides that, it was still difficult for to do new tasks because it had to figure out how to carry out duties.

\section{Literature Review}

\subsection{Performance}

\section{1). Definition of performance}

Performance results from work with a strong relationship with the organization's strategic objectives, customer satisfaction, and contribution to the economy. According to Armstrong and Baron (in Wibowo 2017: 7), performance is about doing the job and achieving that job. Performance is about what to do and how to do it.

2). Employee performance indicators

According to Wibowo (2017: 86), performance indicators consisted of:

a). Purpose

The purpose is the distinct states that an individual or organization is actively seeking to achieve. This definition implies that the goal is not a requirement, nor is it a desire.

b). Standard

Standards have influential meaning because they tell a goal that can be accomplished. Standard is whether the desired goal can be achieved. Without standards, one does not know when a goal will achieve.

c). Feedback

Between goals, standards, and feedback are interrelated. Feedback reporting progress, whether quality, in achieving the goals defined by the feedback standard is paramount when considering "real goals" over actual goals. Goals that employees can accept are goals that are meaningful and valuable.

d). Tools or facilities

Tools or facilities are resources that can use to help complete goals successfully. Tool or facilities is a supporting factor for achieving goals. Without tools or facilities, specific work tasks cannot perform, and objectives can complete as they should. Without tools, it is impossible to do the job.

e). Compensation

Compensation is a significant prerequisite for performance. Competence is the ability that a person has to carry out the job given to him properly. The person who has to do 
more than just learn about something, the person who has to be able to do the job well. Competence allows a person to realize work-related tasks needed to achieve goals.

f). Motive

It Is a reason or incentive for someone to do something. Managers facilitate motivation to employees with incentives in the form of money, provide recognition, set challenging goals, set reasonable standards, ask for feedback to provide feedback on the freedom to do the job at the time of doing the job, provide the necessary resources and eliminate actions that result in disincentives.

g). Opportunities

Workers need to have the opportunity to show their work performance. Two factors contribute to the lack of opportunities for achievement, namely the availability of time and the ability to meet the requirements.

\subsection{Motivation}

1). Definition of motivation

Robbins states motivation as a process that causes intensity, direction, and individual persistence towards goals. According to Greenberg and A. Baron in Wibowo, motivation is a series of processes that arouse, direct, and maintain human behavior towards achieving goals (Wibowo, 2014: 322).

2). Motivation indicators

According to Frederick Herzberg in Hasibuan (2016), the indicators that affect motivation are:

a). salary

A salary can measure through an adequate salary, and the amount follows the standard of quality of life.

b). Giving incentives

They are giving incentives, as measured by giving bonuses from time to time to stimulate work and job performance.

c). Assign employees to an appropriate place

In this case, it measures by selecting appropriate needs, paying attention to abilities, paying attention to education, paying attention to experience, giving jobs according to ability.

d). Creating a sense of safety in the future

We are creating a sense of safety in the future, such as indicators of organizing old-age insurance, paying pensions, providing housing.

e). Pay attention to the workplace environment

As measured by a comfortable workplace, sufficient light, away from pollution and hazards.

f). Paying attention to opportunities to progress

Paying attention to opportunities for progress, as measured by providing development efforts, courses, training.

\subsection{Competence}

1). Definition of competence

Competence is the ability to carry out a job or task based on skills and knowledge, and support by the work attitude demanded by the job (Wibowo, 2014: 271). 
2). The characteristics of the competence

According to Wibowo (2014: 273) states that there are five types of competency characteristic, that are:

a). A motive is something that people consistently think or want that causes an action.

b). Traits are physical characteristics and consistent responses to situations or information.

c). Self-concept is a person's attitude, values, or self-image.

d). Knowledge is information held in a specific field.

e). The ability to pursue certain physical or mental tasks.

\section{Research Method}

\subsection{Data}

This research was an associative study, according to Sugiyono (2017), which is research that aims to determine the relationship between two or more variables. The data used in this study were primary data and secondary data. The data collection techniques were questionnaires and documentation. The population in this study was the human resources Family Hope Program, which was 133 populations, and the number of samples was 57 respondents. The data analysis in this research was qualitative and quantitative.

The data collection used was a questionnaire. According to Sugiyono (2013), a questionnaire is a data collection technique carried out by researchers by providing sheets containing written questions to be answered by respondents. Before the questionnaire was distributed to the respondents, the instrument was tested using the validity test of the contents of the statement. In line with Fauzi, Dencik, dan Asiati's (2019) statement, the item validity test was carried out to measure the instrument's validity. In addition, the data reliability test was also carried out. Fauzi et al. (2019) stated that relevance is the extent to which a measurement can be trusted. To test the reliability of the data, the Cronbach Alpha statistical test was used. A construct is said to be reliable if the Cronbach Alpha value is greater than 0.60. If Cronbach Alpha approaches one, data reliability will be more reliable (Ghozali, 2013).

\subsection{Multiple Linear Regression Analysis}

According to Ervita and Kholilah (2017), Multiple linear regression analysis is an analysis technique that describes the relationship or influence between dependent variables and multiple independent variables. Multiple regression analysis that describes the relationship between dependent variables and more than one independent variable.

$$
Y=a+b_{1} X_{1}+b_{2} X_{2}+\mathrm{e}
$$

Where :

$$
\begin{array}{ll}
\mathrm{Y} & =\text { Performance } \\
\mathrm{X} 1 & =\text { Motivation } \\
\mathrm{X} 2 & =\text { Competence } \\
\mathrm{a} & =\text { Constant Value, The intersection of line on the } \mathrm{X} \text { axis } \\
\mathrm{b} 1 \mathrm{~b} 2 & =\text { the coefficient number of each variable } \mathrm{X} \\
\mathrm{e} & =\text { error }
\end{array}
$$

\subsection{Testing Together (Test F)}


According to Iqbal Hasan (2012), the F test is statistical for the regression coefficient that simultaneously or jointly affects $\mathrm{Y}$.

Testing criteria as followed:

Ho: rejected and $\mathrm{Ha}$ accepted if F-count $>$ F-table with Sig 0.10

Ho: was accepted, and Ha was rejected if $\mathrm{F}_{\text {-count }} \leq \mathrm{F}_{\text {-table }}$ with Sig 0.10

Ho: There was no effect of motivation and competence on HR performance of

The Family Hope Program in Banyuasin District

Ha: There was an Effect of Motivation and Motivationon HR Performance of

The Family Hope Program in Banyuasin District.

\subsection{Partial Testing (t-test)}

According to Iqbal Hasan (2012), the t-test is a statistic for the regression coefficient with only one regression coefficient that affects Y.

Testing criteria as follows:

Ho: was rejected, and Ha was accepted if $\mathrm{t}$-count $>\mathrm{t}$-table with Sig 0.10

Ho: was accepted, and Ha was rejected if the $\mathrm{t}_{\text {-count }} \leq \mathrm{t}_{\text {-table }}$ with $\mathrm{Sig} 0.10$

Ho: There was no partial effect of motivation and competence on HR performance of The Family Hope Program in Banyuasin District

Ha: There was a partial effect of motivation and competence on HR performance of The Family Hope Program in Banyuasin District

\section{Findings and Discussions}

The validity test was needed to obtain a valid instrument, and it meant the right instrument to measure what should be measured. The validity test could be done by correcting the score of each questionnaire item. The validity of the instrument was calculated using the Statistical Product and Service Solution (SPSS) program. This trial was conducted on respondents. The results of this validity could be seen in the table below.

Table. 1. Validity Test Results

\begin{tabular}{|c|c|c|c|c|}
\hline Variables & $\begin{array}{l}\text { Questions } \\
\text { (Indicator) }\end{array}$ & $\mathbf{R}_{\text {-count }}$ & $\mathbf{R}_{\text {table }}(\mathbf{n}-\mathbf{2})$ & Description \\
\hline $\begin{array}{l}\text { HR Performance } \\
\text { of The Family } \\
\text { Hope Program } \\
\text { (Y) }\end{array}$ & $\begin{array}{l}\text { Y.P1 } \\
\text { Y.P2 } \\
\text { Y.P3 } \\
\text { Y.P4 } \\
\text { Y.P5 } \\
\text { Y.P6 }\end{array}$ & $\begin{array}{l}0,354 \\
0,390 \\
0,342 \\
0,724 \\
0,440 \\
0,367\end{array}$ & 0,306 & $\begin{array}{l}\text { Valid } \\
\text { Valid } \\
\text { Valid } \\
\text { Valid } \\
\text { Valid } \\
\text { Valid }\end{array}$ \\
\hline $\begin{aligned} \text { Work } & \text { Motivation } \\
\left(\mathrm{X}_{1}\right) & \end{aligned}$ & $\begin{array}{l}\mathrm{X}_{1} \cdot \mathrm{P} 1 \\
\mathrm{X}_{1} \cdot \mathrm{P} 2 \\
\mathrm{X}_{1} \cdot \mathrm{P} 3 \\
\mathrm{X}_{1} \cdot \mathrm{P} 4 \\
\mathrm{X}_{1} . \mathrm{P} 5\end{array}$ & $\begin{array}{l}0,398 \\
0,716 \\
0,560 \\
0,717 \\
0,763\end{array}$ & 0,306 & $\begin{array}{l}\text { Valid } \\
\text { Valid } \\
\text { Valid } \\
\text { Valid } \\
\text { Valid }\end{array}$ \\
\hline
\end{tabular}




$\begin{array}{lllll}\text { Competency }\left(\mathrm{X}_{2}\right) & \mathrm{X}_{2} \mathrm{P} 1 & 0,360 & & \text { Valid } \\ & \text { X2P2 } & 0,675 & & \text { Valid } \\ & \text { X2P3 } & 0,513 & 0,306 & \text { Valid } \\ & \text { X2p4 } & 0,337 & & \text { Valid } \\ & \text { X2P5 } & 0,575 & & \text { Valid } \\ & \text { X2P6 } & 0,513 & & \text { Valid }\end{array}$

\section{Source: Based on SPSS calculations}

The validity test results showed that the value of r-count for each question for each variable of motivation and competence on performance was greater than the r-table. Thus the questionnaire used by the motivation and competency variables for performance was valid.

To determine the reliability of the questionnaire, the author used the Cronbach calculation technique, where the calculations used the help of the SPSS program. The reliability Criteria test for a variable was reliable if it had a Cronbach's alpha value $>0.60$. Here were the results of the reliability calculation.

Table 2. Reliability Test Results

\begin{tabular}{llll}
\hline Variables & $\begin{array}{l}\text { Cronbach's } \\
\text { Alpha }\end{array}$ & $\begin{array}{l}\text { Reliability } \\
\text { Standards }\end{array}$ & Description \\
\hline $\begin{array}{l}\text { HR } \\
\begin{array}{l}\text { Performance of } \\
\text { The Family }\end{array}\end{array}$ & 0,674 & 0,6 & Reliable \\
$\begin{array}{l}\text { Hope Program } \\
\text { Work } \\
\text { Motivation }\left(\mathrm{X}_{1}\right)\end{array}$ & 0,832 & 0,6 & Reliable \\
& 0,725 & & Reliable \\
\hline
\end{tabular}

Source: Based on SPSS calculations

Based on table 2, it could be seen that the Cronbach Alpha value of the performance variable was 0.674 and motivation variable was 0.832 , and the competence variable was 0.725 . The three variables above had a value greater than 0.6 . This showed that the instrument for each variable was reliable.

\section{a. Multiple Linear Regression Analysis}

According to Sugiyono (2013), Multiple linear regression analysis is an analysis technique that describes the relationship or influence between dependent variables and multiple independent variables. Multiple regression analysis that describes the relationship between dependent variables and more than one independent variable. Multiple linear regression analysis used the SPSS program. The results of multiple linear regression could be seen in table 3. 
Table 3. Multiple Linear Regression Analysis

\begin{tabular}{|c|c|c|c|c|c|c|}
\hline \multirow{2}{*}{\multicolumn{2}{|c|}{ Model }} & \multicolumn{2}{|c|}{ Unstandardized Coefficients } & \multirow{2}{*}{$\begin{array}{c}\begin{array}{c}\text { Standardized } \\
\text { Coefficients }\end{array} \\
\text { Beta }\end{array}$} & \multirow[b]{2}{*}{$\mathrm{t}$} & \multirow[b]{2}{*}{ Sig. } \\
\hline & & B & Std. Error & & & \\
\hline \multirow[t]{3}{*}{1} & (Constant) & 8.526 & 2.172 & & 3.925 & .000 \\
\hline & Motivation_X1 & .417 & .089 & .528 & 4.683 & .000 \\
\hline & Competency_X2 & .209 & .094 & .249 & 2.213 & .031 \\
\hline
\end{tabular}

a. Dependent Variable: Performance _ Y

Based on Table 3. The results of multiple linear regression tests were obtained using the SPSS program. Obtained the effects of work motivation and work competence on HR performance of The Family Hope Program in Banyuasin District could be described by the multiple linear regression equation as followed:

Formula : $\quad \mathrm{Y}=\mathrm{a}+\mathrm{b} 1 \mathrm{x} 1+\mathrm{b} 2 \times 2+\mathrm{e}$

$$
\mathrm{Y}=8,526+0,417 \mathrm{X} 1+0,209 \mathrm{X} 2
$$

The regression constancy value was 8,526 , indicating that motivation and competence with stable conditions or $\mathrm{X}=0$, then the human resource performance of The Family Hope Program in Banyuasin District was 8.526.

The coefficient value of the work motivation variable, amounting to 0.417 (positive), showed that the work motivation variable had a positive effect on human resources performance. It means that if there were an increase in work motivation, the performance of human resources would increase, and vice versa if the work motivation decreases in a negative direction, then human resources performance would below.

The coefficient value of the work competency variable, amounting to 0.209 (positive), showed that the job competency variable had a positive effect on human resources performance. If there were an increase in the coefficient of work competence in a positive direction, then human resources performance would increase, and vice versa; if the coefficient of work competence decreased in a negative direction, the employee performance would below.

Table 4. ANOVA

\begin{tabular}{|ll|r|r|r|r|r|}
\hline Model & Sum of Squares & Df & Mean Square & F & Sig. \\
\hline 1 & Regression & 66.226 & 2 & 33.113 & 23.392 & $.000^{\mathrm{a}}$ \\
& Residual & 76.441 & 54 & 1.416 & & \\
& Total & 142.667 & 56 & & & \\
& & & & & \\
\hline
\end{tabular}

a. Predictors: (Constant), Competency_X2, Motivation_X1

b. Dependent Variable: Performance_Y

b. Hypothesis testing

Based on Table 4 ANOVA, it could be seen that the value of F-count (23.392) > F-table (2.40) with a sig. F $0.000<0.1$ (significant). There was an effect of work motivation and work competence on human resources performance of the Family Hope Program in Banyuasin District. 
The results of the study in Table 3 using the t-test of the motivation variable obtained the value of $t$ count $>t$ table $(4.683>1.674)$ and a significant level $(0.000<0.10)$. So it could be concluded that the Motivation (X1) had a significant effect on the human resources Performance of The Family Hope Program in Banyuasin District.

The results of the study using the t-test of the competency variable obtained $t$ value $>t$ table $(2,213>1,674)$ and a significant level $(0.031<0.10)$. So it could be concluded that the Competency Variable (X2) had a significant effect on the human resources Performance of the Family Hope Program in Banyuasin District.

Table 5. Coefficient Determination

\begin{tabular}{|l|r|r|r|r|}
\hline Model & \multicolumn{1}{|c|}{$\mathrm{R}$} & R Square & Adjusted R Square & $\begin{array}{c}\text { Standard Error of } \\
\text { the Estimate }\end{array}$ \\
\hline 1 & $.681^{\mathrm{a}}$ & .464 & .444 & 1.190 \\
\hline
\end{tabular}

a. Predictors: (Constant), Competency_X2, Motivation_X1

Based on table 5 above, the value of Adjusted R Square was $0.464 \times 100 \%=46.4 \%$. It meant that motivation and competence could contribute to the ups and downs of changes that occurred in HR performance with the resulting contribution of $46.4 \%$, while the remaining $53.6 \%$ explained by other variables not included in this study.

\section{Conclusion}

Based on the results of the research and discussion that had been described, it could be concluded that:

a. The results of hypothesis testing through the F-test (together) showed a significant effect of motivation and competence on human resources performance of the Family Hope Program in Banyuasin District.

b. The results of hypothesis testing through the t-test (partial) showed a significant effect of motivation on human resources performance of the Family Hope Program in Banyuasin District.

c. The results of hypothesis testing through the t-test (partial) indicated a significant effect of competence on human resources performance of the Family Hope Program in Banyuasin District.

\section{References}

Ervita dan Kholilah (2017). Buku Ajar Statistik 1. Jurusan Manajemen Fakultas Ekonomi dan Bisnis Universitas Muhammadiyah Palembang.

Fauzi, F., Dencik, AB., dan Asiati, D.I. (2019). Metodologi Penelitian untuk Manajemen dan Akuntansi. Salemba Empat

Ghozali, Imam. (2013). Aplikasi Analisis Multivariat dengan Program IBM SPSS. Edisi 7. Universitas Diponegoro.

Hasibuan, Malayu S.P. (2016). Manajemen Sumber Daya Manusia. Edisi Revisi. Penerbit PT Bumi Aksara. 
Iqbal Hasan (2012).Pokok-pokok Materi Statistik 2 (statistic inferensif). Bumi Aksara.

Sugiyono . (2013). Metode Penelitian Bisnis. Alfabeta.

Sugiyono. 2017. Metode Penelitian Bisnis. Alfabeta.

Sutrisno, E. (2017). Manajemen Sumber Daya Manusia. Edisi Pertama. Kharisma Putra Utama.

Wibowo (2017). Manajemen kinerja. PT. Raja Grafindo Persada.

Wibowo. (2014). Manajemen Kinerja. (Edisi Keempat). PT. Rajagrafindo Persada.

Wibowo. (2016). Manajemen Kinerja. Edisi Kelima. Penerbit Penerbit PT. RajaGrafindo Persada.

\section{Copyrights}

Copyright for this article is retained by the author(s), with first publication rights granted to the journal.

It is an open-access article distributed under the terms and conditions of the Creative Commons Attribution license (http://creativecommons.org/licenses/by/4.0/) 